\title{
Human Smuggling on Europe's Eastern Balkan and Eastern Borders Routes
}

DOI: $10.11567 /$ met.34.1.3

UDK: 314.15:343.343.62(4-11-04+497-04) 343.343.62:343.9.024(4-11-04+497-04)

Pregledni rad

Primljeno: 11.04.2018. Prihvaćeno: 05.07.2018.

\author{
Johan Leman
}

Faculty of Social Sciences, KU Leuven, Leuven

johan.leman@kuleuven.be

\section{Stef Janssens}

Myria - Federal Migration Centre, Brussels

janssensstef@hotmail.com

\begin{abstract}
SUMMARY
The authors propose an analysis of the developments in migrants' smuggling (and indirectly also in transit migrations) on the Eastern Balkan (Bulgaria-Romania) and Eastern Borders (Moldova, Ukraine, Belarus) routes from around 2015. For some transit migrants (and migrants' smugglers), with the severe controls on the Western Balkan route and after the EU-Turkey deal of April 2016, the new routes, each with its own already decennia-long smuggling tradition, have become a possible alternative for the Western Balkan route. Starting from the statistics, the authors show that there surely is a partial integration of both new routes, but that it is not very clear in which proportion and how it may happen. They provide the figures about what is already known today. But at the same time, one discovers that, due to the problems of official labelling and to a lack of an all-inclusive approach, for which only partial pieces of the routes are taken in consideration, it is difficult to come to a good understanding of the processes and of the complexity of the Smuggling of Migrants (SoM) business. Instead of only putting partial findings together, it should be possible to follow the processes from the destination to the arrival countries. In most cases, the countries on the Eastern Balkan and Eastern Borders routes only function as transit countries. The structure as a whole remains out of sight. To show the importance of this all-inclusive approach, the authors analyse some files from one of the possible destination countries (Belgium). They conclude with suggestions for further research.
\end{abstract}

KEY WORDS: Eastern Borders, Eastern Balkan, transit migrations, migrants' smuggling 


\section{INTRODUCTION}

South- and Central-Eastern European countries find themselves at the crossroads of important migration and asylum pathways from the South and East to the North and West. Migration through the complex region is often irregular. People cross borders without authorization or with fake papers. It may happen with the aid of facilitators who may or may not be part of smuggling networks. It may also be part of an all-inclusive project starting from a faraway country of origin in search of a country of destination in northern or western Europe.

Since the recent Syria war onwards, the Western Balkan route (Greece, Macedonia, Serbia...) had become a major migration and smuggling route. ${ }^{1}$ But since 2015 onwards and surely after the EU-Turkey deal of April 2016, ${ }^{2}$ more migrants started to use the Eastern Balkan and Eastern Borders routes. ${ }^{3}$ On both routes one may distinguish an almost three-decennia-old tradition of migrant smuggling. Migrants, refugees and smugglers who want to avoid the Western, Central and Eastern (i.e. "Western Balkan") Mediterranean routes, may see these routes as interesting alternatives.

The countries that are concerned by both routes do not form a unity. Bulgaria and Romania are a first cluster. Already in the 1990s, in both countries, a strong Smuggling of Migrants (SoM) business for regionals was supported by visa trafficking (Leman, 2002; Leman and Janssens, 2015). Bulgaria and Romania are currently subject to a flow of transit refugees arriving via Turkey and avoiding Greece. Since 2015, and still more after the April 2016 EU-Turkey deal, for refugees from Syria, Iraq, Afghanistan and Africa, both countries have become an alternative for the Western Balkan route. ${ }^{4}$

The CIS countries, Moldova, Ukraine and Belarus ${ }^{5}$ form a second cluster. They have their own traditional migration flows and smuggling traditions

1 For the Western Balkan route, that we will not discuss in our paper; see Angeli and Triandafillidou, 2017.

2 EC Communication "Towards the Reform of the common European asylum system and enhancing legal avenues to Europe," a Communication from the Commission to the European Parliament and the Council (Brussels, 06.04.2016).

3 Another important route that has emerged is the Greece-Albania-Montenegro-BosniaCroatia route, with 1,500 arrivals in Montenegro in the first 5 months of 2018 and a lowering of the prices for a passing from Bosnia and Herzegovina to Croatia from $€ 1,000$ to 100-300. We will not discuss this Southern route (Il Piccolo, 17.08.2018).

4 As an example for a search for alternative routes, one may read for example Quercia (2017: 20) and the article available at http://www.channelnewsasia.com/news/world/people-smugglers-test-new-migrant-sea-route-through-romania-9228702

5 CIS: Commonwealth of Independent States, the alliance of former Soviet republics formed in December 1991. 
for regional and non-regional migrants who want to enter the European Union via the Eastern Borders route. The non-regionals come from Asia, through Russia. ${ }^{6}$ After the April 2016 deal, this route has integrated a category of refugees arriving via Bulgaria-Romania, or directly by air or via other countries in the (Near) East. ${ }^{7}$

Finally, there are the Visegrad Four: Slovakia, the Czech Republic, Poland and Hungary. They see themselves as transit and dispatching countries. $^{8}$

In the past, facilitators on the Eastern borders, especially with Finland and Latvia, were Chechen Russians who were part of a traditional smuggling network. They continue to do the job (Europol, 2016: 10). But it is often the Polish and Romanian smugglers who are active in transporting the former Western Balkan migrants to the United Kingdom via the Eastern Borders route (Europol, 2016: 8).

Which strategies do the authorities in the countries of our three clusters develop to counter the SoM activities? They all adhere to the Palermo Protocol against SoM and THB (Trafficking of Human Beings). But the courts only rarely treat SoM under this charge. Polish authorities, for example, have tailored the regulations and sanctions completely in accordance with EU norms (see Article $264 \S 1$ of the Penal Code) and adhere to the Palermo Protocol(s), but they do not treat many cases under the SoM label. It means that it is not easy to quantify the SoM phenomenon.

In our paper, we will propose an analysis of the situation on the Eastern Balkan and Eastern Borders routes in the 2015-2018 period. It will be based on dispersed official data. The reader should be aware that, for various reasons that will become clear in our paper, this will lead to a quite incomplete picture. It may be an invitation for further research. The second part will complement the first findings with findings from some juridical files that

6 Until 2015 there were some 1,500 detections yearly, with Ukraine being the most important transit country for Georgians, Russians, Afghans, Somalis and others entering via the Russian Federation. Later on, Norway and Finland, which will not be discussed in this paper and which are on the Arctic route, have also become important transit countries (Frontex, 2016).

7 The Syrians and Iraqis may receive offers including a visa for Russia, Ukraine and Moldova. "The smugglers, however, gave the impression that from these countries, Syrians and Iraqis would be able to move into the EU territory" (UNHCR, 2017b: 28).

8 Poland, Slovakia, Hungary and Romania are FRAN members (Frontex Risk Analysis Network, from which only Norway and Finland are missing). Ukraine, Belarus and Moldova are EaP-RAN countries (Eastern Partnership Risk Analysis Network), to which Armenia, Azerbaijan and Georgia also belong. Albania, Montenegro, Bosnia and Herzegovina and the Baltic countries (Estonia, Latvia and Lithuania) will not be discussed. 
we were able to study in Belgium. This part will also provide an incomplete view of the phenomenon, but it will lead to an interesting realization that we need an all-inclusive approach that looks further than the data we get from local country situations. In the third part and before reaching some conclusions, we will describe some future policy and research challenges as we see them.

\section{OFFICIAL LOCAL DATA ON MIGRANT SMUGGLING FROM THE THREE COUNTRY CLUSTERS}

Official national sources in Eastern European countries mainly use labels such as "illegal border crossing" and "facilitators" for SoM and illegal migrations. ${ }^{9}$ It is difficult to find out from the official sources how many of these crossings are related to illegal migrations or are the result of SoM. ${ }^{10}$ Smuggled migrants may not at all be related to smugglers. They may apply for asylum and find a place in an asylum or detention center where they will not be known as smuggled migrants. Later, they may be contacted by facilitators who are part of a bigger SoM network, to which they pay before departure.

First, we will focus on Bulgaria-Romania-(Moldova) as an alternative route for Western Balkan route candidates. Second, we will analyze what happens on the Eastern Borders route. We will try to understand the convergence between both routes.

\footnotetext{
9 To be precise, from informal talks with some magistrates in Belgium we learn that on the field, magistrates who are specialized in SoM often give priority to acting against SoM networks rather than combating illegal migration or smuggled migrants. It is the official labeling that does not follow.

10 Most official data on SoM are supplied by European institutes.
} 
Figure 1. A map of the transit migration and SoM routes

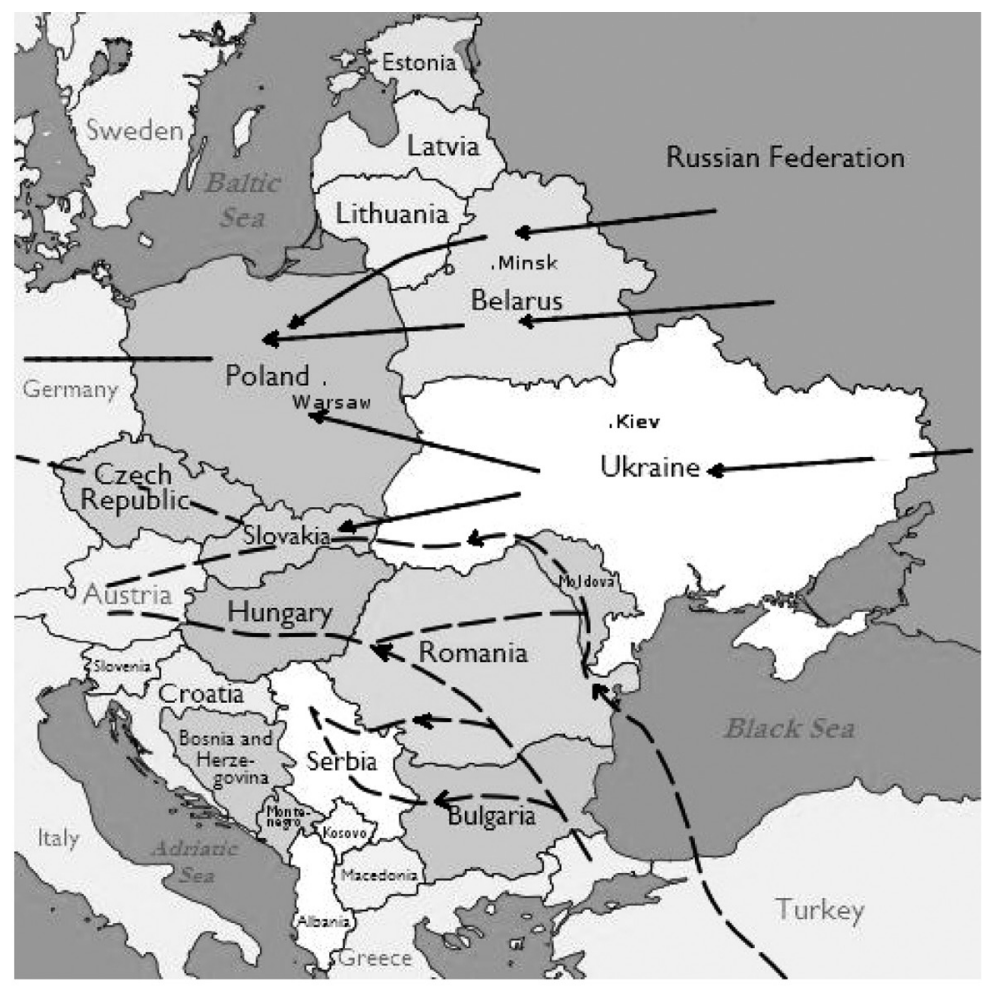

Legend: The alternative for the non-Western Balkan route (Bulgaria-Romania): dotted lines; The Eastern Balkan route for regionals and non-regionals: continuous lines

Source: Neutral map downloaded from https://www.tripsavoy.com/maps-of-eastern-europe-4123431 (C Digital Vector Maps - Modified by Kerry Kubilius); authors indicated the migration routes based on their findings.

\section{On the Eastern Balkan route (Bulgaria-Romania)}

Referring to Bulgarian national sources, Kyuchukov (2016:3) writes that 246 (in 2009), 235 (in 2010) and 411 (in 2015) migrant smugglers were apprehended (ICMPD, 2013: 68-70). The SoM business in Bulgaria was mostly led by Turkish (42\%) or Bulgarian (34\%) entrepreneurs. Bulgaria constructed anti-refugee facilities at the Turkish-Bulgarian border, but not at the borders with Greece, nor with the Republic of Macedonia and Romania. ${ }^{11}$ Even if Bulgarian authorities fear that refugees will also use the Greek-Bulgarian

11 Bulgaria never wanted to build anti-refugee walls at its borders with European member states (Kyuchukov, 2016: 14-16). 
border to enter the country, they see it as their most important task to control the border with Turkey since there is no agreement with Turkey to take immigrants back and Turkey is a non-EU member state. ${ }^{12}$

Refugees, whether smuggled or not, have tried to travel to Vienna via Bulgaria-Romania concealed in vans and trucks. As a consequence, since mid-2016 onwards, there have increasingly been large-scale checks on the Bulgarian border with Serbia. At the same time, Hungary intensified its checks at the border with Romania (IOM, 2017b: 20). The repressive controls on the Serbian-Bulgarian and the Serbian-Romanian borders increased (Frontex, 2017b: 13).

That led to a shift and to a more dangerous border crossing from Bulgaria to Romania, using small boats to cross the Danube (UNHCR, 2017a: 4-5) with an objective to enter Serbia/Hungary, or Moldova via a new way. In Romania, in 2015; 392 groups of smuggled migrants and 211 migrant smugglers, and in 2016; 1,650 smuggled migrants divided in 351 groups, and 140 migrant smugglers were apprehended. ${ }^{13}$ Note for Romania, that in 2015; 1,232 foreign citizens crossed the Danube border illegally to enter Romania with the help of migrants' smugglers, in groups from three to 132 (Schiopu and Dumitrache Ionescu, 2016). Another dangerous Danube crossing was discovered in the East. Migrants enter Romania-Moldova and go from there to Ukraine. Dangerous border crossings support the impact of the SoM business (UNHCR, 2017b: 10).

In the meantime, some SoM entrepreneurs searched for yet another possible new route, via the Black Sea. "(T)he Romanian coast guard told Reuters on Monday that 475 people reached its shores in about one month in August-September (2017), including from Iraq and Iran. Seven people smugglers from Turkey, Bulgaria, Syria, Iraq and Cyprus had been arrested. (...) 'While it is too early to talk about the opening of a new migratory route, the recent incidents of intercepted wooden boats with migrants on the Black Sea suggest that smugglers might be looking to revive this route,' said a Frontex spokesman. Frontex said the Black Sea route was last active in 2014 but did not expect it to develop on a large scale due to difficult sailing conditions on the Black Sea, especially as autumn nears." (Reuters, Press conference 19.09.2017). ${ }^{14}$

12 Turkey signed Readmission Agreements with Greece, Romania and the Republic of Moldova, but not with Bulgaria.

13 Poliția de Frontieră Română, Analiza activității Poliției de Frontieră Române pe anul 2016, Sept. 2017.

14 Read more at http://www.channelnewsasia.com/news/world/people-smugglers-test- 
It brings us to the east of Romania and to Moldova. Moldova's situation is specific. In a sense, it is strictly allied to Romania (same language) but it is a CIS country and an easy gateway to Ukraine. "The majority of Moldovan citizens take advantage of the visa-free regime with the CIS and enter Ukraine legally by rail, road or air. Since 2006, the entry is granted upon a presentation of the passport" (Mosneaga, 2013: 1). At another border, the Romanian one, as Romania became an EU member state in 2007, entrance from Moldova to Romania requires a visa. This requirement can be avoided in two ways, either via travel agencies, or via the system of "restorative historical justice" that allows some Moldavians to have Romanian nationality. Alternatively, regionals can hide in trucks to cross the border with Romania, or they can buy fake Romanian ID documents. A migrant who does not opt for a transit via Romania (and still a piece of the Western Balkan route), can travel by his or her own means to Ukraine and then cross a 100-km-long wooded border with Slovakia with the aid of facilitators. This was the traditional smuggling practice in Moldova before 2013. The facilitators at the Slovak border worked independently, while in recent years, some of them have become integrated in a larger SoM network.

Since 2015 and surely since April 2016, Moldovan SoM entrepreneurs have started to use their traditional smuggling routes as an alternative for the new "former Western Balkan route candidates", in order to transfer them via Romania and hidden in trucks to Hungary (UNHCR, 2017b: 28), ${ }^{15}$ or to send them via Ukraine and a piece of the Eastern Borders route to Slovakia.

\section{On the Eastern Borders route: old and new practices}

From Moldova (Republic of Moldova. Migration Profile Light, 2015) one can travel without any problem to Ukraine and then to Slovakia or Poland, with the help of facilitators, again integrated or not in an ampler SoM network. Moldova is the link with the Eastern Borders route, where the strategic position of Ukraine with its own particular SoM tradition is fundamental.

Ukrainian nationals do not need a visa and do not need SoM to leave Ukraine for the European Union (Fargues, 2013; Markov, 2009; Jaroszewicz and Kindler, 2015: 12). That explains why SoM entrepreneurs in Ukraine are more interested in non-regionals than in regionals (ICMPD, 2013: 269;

new-migrant-sea-route-through-romania-9228702. See also Quercia (2017: 20): In August and September 2017 the landings of migrants using the Black Sea route are already higher than in the whole 2014, namely more than 500 versus 430 people; and see IOM, 2017b: 8, about a smuggling event on 13 August 2017 by yacht on the Black Sea.

15 See also Toma, Toderita and Damian (2017: 21). 
Leman and Janssens, 2015). Their interest for Ukrainian regionals remains limited to candidates for the United Kingdom. Most of their clients in the past were migrants from Russia, Uzbekistan, Azerbaijan, Moldova and Georgia, India or China. ${ }^{16}$ They were transit migrants who tried to arrive in Germany via Poland. Today new, former Western-Balkan route candidates, have joined coming via Bulgaria-Romania-Moldova.

A third CIS country that needs explanation as a transit country is Belarus. Until recently, this country was Russia-oriented. But interestingly, a 2017 Report from Frontex (2017a: 22) drew attention to the fact that in 2016, there was an increase in the number of Tajik transit migrants via Belarus. While 3,628 Tajiks were denied access to the EU/Schengen area in 2015, this number rose to 7,099 in 2016. The depreciation of the Russian ruble makes employment in Russia less attractive for them. However; unfortunately, from the official sources we do not learn if SoM is involved in this issue.

Belarus and Ukraine are the two countries with the most border violations with Poland. Smuggling to Poland, a country currently part of the Visegrad Four, is not a new phenomenon, either in Ukraine or in Belarus. ${ }^{17}$ Once in Poland, the migrants, smuggled or not, take one of the following five routes: from Poland to the United Kingdom (under control of Polish and Ukrainian smugglers, using Polish official documents); Poland-Germany-France/Belgium; Poland-Czech Republic-Austria; Poland-Sweden/ Norway; and from Lithuania via Poland to Western Europe. Even if there are clearly a lot of SoM activities, not many investigations were initiated under the label of SoM (9 in 2014, 3 in 2015 and 4 in 2016), and not many crimes were confirmed as such: only 2 (2014), 19 (2015), 2 (2016). ${ }^{18}$

Among the Visegrad Four; besides Poland, two other countries take a particular position: the Czech Republic and Slovakia. Both countries see themselves as transit countries (ICMPD, 2013: 94-95). According to a government report, ${ }^{19}$ in the Czech Republic, in 2017 there was nothing to observe for SoM and there were only 120 requests for asylum. ${ }^{20}$ As to Slova-

16 We do not claim that these migrants always engage with SoM entrepreneurs (Jaroszewicz and Kindler, 2015: 17).

17 Facilitators over the whole length of the Eastern Borders, detected at border points, are citizens of Belarus, Turkey, Georgia, Armenia and Tajikistan (Frontex, 2017c: 7). From the yearly 2017 report we learn that over the whole year "most detections were recorded by Finland (52\%), Belarus (19\%) and Latvia (14\%)." Thus, surely not by Ukraine (Frontex, 2017a: 10).

18 Information provided by Prof. Zbigniew Lasocik (Warsaw University), 2017.

19 Only available in Czech, information provided by Vačkov Veselin, $\mathrm{PhD}$, managing editor at Lidové Noviny (Prague), 2017.

20 As of mid-2017 there have been only 64 asylum seekers in the Czech state-operated asy- 
kia, we are informed that from there, transit migrants may be brought via Austria to Italy, Switzerland, France or Spain. It is an eight-hour trip from one border to the other one with the aid of facilitators (cost: EUR 450) (ICMPD, 2013: 241-242). In 2010, 458 smuggled people were apprehended in Slovakia, together with 147 smugglers. Both countries have a paragraph in their legislation against "enabling illegal border crossing". It may be used in SoM cases. However, no court decision to date has been based on it. The facilitators function at the borders or contact migrants in detention and reception centers.

\section{Findings about integration of the Eastern Balkan route in the Eastern Borders one}

There are obviously three important candidate countries of provenance for the integration of both the Eastern Balkan and the Eastern Borders routes: Afghanistan, Syria and Iraq (Frontex, 2016). ${ }^{21}$ In Afghanistan, candidate migrants use local smuggling agents who propose all-inclusive trips (also for underage boys). In Syria and Iraq, the situation is different. It is the fellow Syrians and Iraqis who have already made the journey, who inform candidate refugees about the ways, including the new ones, to be followed and about the smugglers and facilitators who can be trusted where needed. Negotiations between the candidates and the smugglers are done via private channels (Viber, Imo, WhatsApp...). Syrians and Iraqis prefer not to use smugglers. They do it only when needed. It is different for Afghans (UNHCR, 2017b: 10). ${ }^{22}$ What do we know about a possible integration of the Eastern Balkan route and the Eastern Borders route, if our information is only based on local official figures? Not much.

Concerning the Eastern Borders routes and the borders between the CIS countries and its European Union neighbors (Hungary, Poland, Slovakia), Frontex writes that "the numbers of illegal border crossings remained stable, oscillating around 1,500 each year" (Frontex, 2018: 2). Frontex concludes that along the Eastern land border, "abuse of legal travel channels is more common than illegal border-crossing, mainly by citizens of the CIS (Commonwealth of Independent States) including Georgians" (Frontex, 2018: 2).

A second finding concerns the situation on the Bulgaria-RomaniaMoldova route. From 2013 onwards, the detour via Bulgaria for Western

lum centers.

21 Somalis and other Africans prefer the Arctic route, that is also used by Afghans and Syrians. It is a migration route which has become important since 2015.

22 That smugglers increasingly use the Internet and social media, is also attested in Belgian court cases (Myria, 2017). 
Balkan-transiting migrants is gaining in importance as a result of pushbacks and push-forwards between Serbia and Macedonia. So, from April 2016 onwards, Bulgaria has been witnessing the arrival of 15,962 migrants, mainly Afghans. ${ }^{23}$ Only 5,560 of them remained in Bulgaria. In 2016; 6,447 underage children, mainly Afghans, and to a lesser degree Syrians and Iraqis, requested asylum in Bulgaria, of whom 2,768 (43\%) were unaccompanied minors (UNHCR, UNICEF and IOM, 2017b). ${ }^{24}$ Mid-December 2016, the authorities "had apprehended more than 18,000 foreign nationals who had entered Bulgarian territory without authorization" (Weber, 2017: 12). ${ }^{25}$ Syrians and Iraqis also follow this alternative route. The reality is that from mid-2016 on, one assisted at increasing large-scale checks, this time on the Bulgarian border with Serbia. And for those who tried to enter using the Western Balkan route via Romania, the problem was that Hungary also intensified its checks at the border with Romania (IOM, 2017b: 20). There is clearly a dark number of transit migrants who left for Western Europe, very probably via the Eastern Borders route.

In fact, once in Bulgaria or in Romania, transit migrants and refugees have only three possible choices: they may request asylum, or they may try to transit via Serbia or Hungary (but there are a lot of pushbacks there), or via Moldova and Ukraine. From official statistics we learn that in Bulgaria, out of 15,962 migrants, only 5,560 remained. We finally know from some statistics that, officially, at least some of the transit migrants try to enter Europe via Moldova and Ukraine. However, for a lot of reasons, it seems very difficult to make an estimation of how many there are. One may guess at the possible reasons. Can transit migrants cross borders illegally without being seen, since facilitators are efficient and know very well the places where to cross borders? Do they receive ID cards of CIS nationals, for example Ukrainians? It is difficult to provide an interpretation.

23 By comparison, in Hungary, as of 16 November 2016 there have only been 460 migrants/ refugees (IOM, 2017a: 11).

24 In patriarchal Afghanistan, many parents regard migrating as a good thing for their underage children (UNHCR, 2017b: 16), mostly boys.

25 In the same period Italy had 181,436 arrivals, Greece 176,906 and Spain 13,246 (IOM, 2017a: 9). 


\section{INSIGHTS BASED ON COMPLEMENTARY JURIDICAL FILES FROM A DESTINATION/TRANSIT COUNTRY}

In order to understand the phenomenon better, we will add data taken from official sources in countries farther on the route, already in Western Europe (namely Belgium). This will provide us with an argument to make a plea for a more in-depth and all-inclusive approach to the smuggling business that apparently supports some of the transit dynamics on the Eastern Balkan and Eastern Borders routes.

From Myria ${ }^{26}$ we learn that between January 2015 and February 2016, a Ukrainian smuggling network transported at least 500 Ukrainian citizens from Ukraine via Poland and Belgium to the United Kingdom (price: EUR $5,000)$. Fifteen smugglers were convicted of SoM in Belgium..$^{27}$ The police noted:

"We have established that during the communications (Skype) between smugglers $X, Y$ and $Z$, relatively structured statements were made that can be labeled as relevant for the investigation. In these communications, information from Polish identity cards is transferred, which are then sent back with or without an OK. The communications were mainly about the following two subjects: a) the passing on of Polish phone numbers, and in addition, there was an amount in EUR and a time. This related, with a probability approaching certainty, to the phone numbers of drivers who carry candidates across the French-British border, and the amount to be paid to them as well as the time at which contact should be made with the man; b) the passing on of Polish names, birth dates and alphanumeric information, this being the information from Polish identity cards that have been verified for their usability (whether or not they have been blacklisted)."(Myria, 2017)

What is interesting in this case, is that the link between Ukraine and Poland seems to have an important dispatching role for SoM via the Eastern Borders. It is also important to see that regular phone calls are avoided by these smugglers. Communication is organized by Skype.

26 Myria is the independent Belgian rapporteur on SoM activities in Belgium. It has access to juridical files and court cases.

27 Correctional Court East Flanders, Ghent division, 10 January 2017, G28bis k. Two of the accused smugglers were also convicted of the murder of a Lithuanian lorry driver/smuggler after a financial dispute (sentenced by the Correctional Court of Ghent, 21 February 2017). 
As for Hungary, it is generally known that the measures against migration and refugee transiting are impressive (Weber 2017, 14-15). ${ }^{28}$ Does it exclude migrant smuggling? One may have serious doubts. ${ }^{29}$ From a Belgian court case ${ }^{30}$ we learn, for instance, how Syrian smugglers, active from within Hungary, smuggled migrants between 2013 and 2015 with the aid of a Syrian embassy staff member in France who sold false documents. They were known from previous Hungarian-German smuggling activities and had infiltrated a former Hungarian refugee camp at Debrecen from where they organized their smuggling operations to Germany. And again, concerning Hungary, commenting on the sexual exploitation of unaccompanied child refugees in Europe, Brian Donald, Europol's chief of staff, explains that in Germany and Hungary "an entire [criminal] infrastructure has developed over the past 18 months around exploiting the migrant flow. There are prisons in Germany and Hungary where the vast majority of people arrested and placed there are in relation to criminal activity surrounding the migrant crisis" (Townsend, 2016). But here, it may seem better to speak of THB than of SoM.

As we saw, the Czech Republic and Slovakia continue to perceive themselves as transit countries. However, from some Belgian files we learn that there may be a more complex integration of these countries in the ample migrant smuggling business. When calculated following a local dossier formula, smuggling benefits per person may remain limited to, for instance, EUR 450 for transiting via Slovakia. But when calculated all-inclusively it may concern a business affair of EUR 12,000 per person.

From 2013 to 2015, an Albanian-Czech criminal organization smuggled 94 Albanian nationals, including 13 minors, from Albania via Belgium to the United Kingdom. They had to pay EUR 500 in advance. But the remaining amount, which was to be paid upon arrival in the United Kingdom, varied between EUR 1,500 and 5,000. The accomplices of the two Albanian lead smugglers were mainly Czech drivers, but Slovakian and Lithuanian helpers were also involved. ${ }^{31}$ The criminal gains from the smuggling network amounted to almost EUR 450,000 of which the two lead smugglers each kept approximately EUR 190,000. It makes a difference if the Slovakian

28 See also a map by Giulio Sabbati, EPRS; Data source: Amnesty International (2015); and also in Lilyanova (2016: 3).

29 In the middle of the 1990s a Hungarian border guard noted that only 20 to $25 \%$ of illegal migrants used smugglers, while the same number reached $70 \%$ already in 2004 (Futo, Jandl and Karsakova, 2005: 44). Will it be lower today? Not probable.

30 Judgement of East Flanders, Ghent division court, 16 October 2017, G28m.

31 Correctional Court East Flanders, Ghent division, 2 January 2017, G28m k. 
helpers are treated as facilitators or as active supporters of the global business.

Let us take another example, i.e. of Chinese migrants "transiting via the Czech Republic". ${ }^{32}$

Between 2003 and 2010, a Chinese criminal organization smuggled Chinese nationals to Poland, Belgium and other countries. The migrants had to pay off their smuggling debts by working for many years in Chinese restaurants. All the victims, using a Chinese travel agency and with a visa costing EUR 12,000, came from the same region in China, the province of Zhiejang. The organization structure was extremely sophisticated, with not only activities in Belgium but also in Spain, Portugal, Poland, Hungary... and the Czech Republic! The victims declared that, after working for a few months (in one restaurant!), they would be moved to a different restaurant in another country (see the relation with THB). On arrival in a Schengen country, they were deposited at a refugee reception center where they would apply for asylum. At that moment they were registered in the EURODAC information system for 12 months. That means that had they then be arrested in a different EU member state, they would be deported back to that Schengen country and would not be sent back to China (Myria, 2016).

The question that one may ask oneself, is if an analysis of pieces of routes, without reconstructing the whole route, is sufficient for a real understanding of the dynamics behind the smuggling business, for instance the understanding of the smuggling prices, or even the organization of the smuggling itself. SoM entrepreneurs may be located in countries of provenance, or in countries of final destination and they have a global business approach. It is really a "dynamic transnational service industry that stretches over many countries and borders" (Bilger, Hofmann and Jandl, 2006).

Last case:

From a Belgian juridical file involving the Bulgaria-Romania route, between October 2014 and August 2015, an Iraqi smuggling network smuggled, by means of 129 transports, at least 1,290 Kurds and Syrians, including 22 minors, either via Bulgaria and Romania or via the (here not discussed) Central Mediterranean route to Germany and other countries in Western Europe. The criminal assets of the smuggling network

32 Correctional Court Liege, 28 April 2014, 14th k. Also see: Bruggen slaan, 113 (Myria, 2013) and the website of Myria: www.myria.be/nl/jurisdiction/correctionele-rechtbank-luik-28april-2014. 
amounted to at least EUR 3,125,000. From the conversations intercepted through the phone tap, it appeared that one smuggler told another smuggler that they could count on earning GBP 200,000 in a month. The lead smugglers owned several restaurants and car washes in the United Kingdom. ${ }^{33}$ The smuggling network had contacts with smugglers in Greece, Turkey, Italy, Austria, Hungary, Bulgaria, Romania, the Czech Republic, Slovakia, Serbia and Iraq.

Again, it makes a difference if smuggled migrants are seen, based on non-transnational and only local files, as illegally employed migrants with a local employer that will be sanctioned for illegal employment or if the case is treated in an "all-inclusive" way.

A final observation of another dimension: If one accepts that the SoM business in its various forms remains mainly interested in bringing migrants over to Western Europe, and if the business is researched as a local, and not a global problem, there may also be negligence in some Eastern European countries vis-à-vis those nationals who are active as important SoM entrepreneurs abroad, in Western Europe. May a sentence as "according to Europol, ${ }^{34}$ the most common nationalities of the suspects of criminal networks, coming within the EU and engaged in SoM, are Bulgarians, Hungarians, Poles and Romanians (Europol, 2016: 7), with the suspects being active in the final destination countries such as Germany and Netherlands" (Europol, 2016: 17), be an indication for it?

\section{POLICY AND RESEARCH CHALLENGES}

At this point, before reaching conclusions it may be interesting to see the suggestions for framing and improving the research on our topic: the role of the Eastern Balkan and Eastern Borders routes and their convergence in the SoM business and - something that is not completely related to it - the migration movements.

\section{The need of a multi-level SoM approach}

In most Eastern European countries, except Bulgaria and Romania, the complex, all-inclusive SoM framing very often remains under-researched.

33 Correctional Court East Flanders, Dendermonde division, 25 April 2016, D19D k.

34 Migrant smuggling in the EU, Europol publication report, February 2016, available at https://www.europol.europa.eu/publications-documents/migrant-smuggling-in-eu, p. 10. 
Two examples may illustrate it. On 24 May 2017, Polish Border Guard Officers of the Warmia-Mazury Division undertook illegal employment inspections in a recruitment agency. ${ }^{35}$ The legality of the employment of 189 foreign workers was verified and the inspections found 36 Ukrainians without a work permit. The employer was only accused of violating the 2004 Act on Employment Promotion and Labour Market Institutions, which was formally correct, but it was not examined if there was a systematic structure behind it that could be interpreted as SoM or even THB.

Another case: From EMN (European Migration Network) bulletins we learn ${ }^{36}$ that Polish Border Guard Officers dismantled a Polish-Russian organized criminal group smuggling foreigners across the border. The officers conducted operations in Mazovia, Podlaskie, Lubelskie and the West Pomeranian. The detained persons were charged with leadership of and participation in an organized criminal group "involved in the organization of illegal migration". Why not call it SoM? Very probably because the approach remains limited to a partial interest: are migrations legal or not?

\section{Importance of court case analyses}

For an evaluation of policies on SoM, it is important to use an analysis of court decisions and juridical files. It improves an evidence-based approach and supports the completeness of a multiply leveled analysis. Indeed, court case analyses are composed of documents concerning intercepted telephone calls, ${ }^{37}$ social media messages, interviews with perpetrators and victims, observation reports, house searches and reports from rogatory commissions to other countries, and many important documents with information about the business structure. Myria shows clearly that a court case analysis may lead to a broad and deep approach to the SoM business (Myria, 2017, 2016, 2015).

\section{Place for out-of-the-box reasoning}

It is important not to become victims of our own academic geographic framing. High-level SoM entrepreneurship is as fluid as money. We illustrate that with the Albanian-Czech SoM network that we have already presented in the paragraph about Integrating the routes in an all-inclusive crossnational smuggling project.

35 EMN 19th Bulletin, 02.08.2017, see also EMN (homepage: https:/ec.europa.eu/home-affairs/what-we-do/networks/european_migration_network_en), 24.09.2017.

36 EMN 18th Bulletin, 15.10.2017.

37 In a lot of files, the reports on telephone taps take (much) more than 1000 pages, based on daily reports. 
The two lead smugglers were Albanians. They coordinated their smuggling activities from the United Kingdom. Two accused Czechs were their assistants and travelled constantly back and forth between continental Europe and the United Kingdom. When seeking drivers for their delivery vans, they were mainly looking in the Czech Republic and particularly in the socially impoverished environments of the homeless and drug users. One driver testified that he was offered GBP 4,000-5,000 for transporting six smuggled persons. Others got EUR 2,000 for a smaller transport. The smugglers claimed that they worked according to the commercial principle of "money-back guarantee" and they advertised this to their smuggling clients. What is interesting to see, is that this case puts together countries that do not follow the logic of the migration routes on our map, namely Albania, the Czech Republic, Lithuania, the United Kingdom and Belgium. Also, Czech smugglers were clearly more than local facilitators.

This case shows some non-predictability when it concerns the routes used by the top-entrepreneurs.

\section{SoM is a big business: smuggling prices}

From academic and N.G.O. publications as well as from court cases (the information gathered from wiretaps or victim declarations), we may learn about smuggling prices, for instance the fact that for transferring migrants through Bulgaria alone, smugglers request EUR 3,000 (Remáč and Malmersjo, 2016: 3) and from Serbia to Austria between EUR 700 and EUR 1,200 per person (Angeli and Triandafyllidou, 2017: 113). In Moldova, for hiding in trucks, one may ask a price fluctuating between EUR 2,000 and EUR 2,500 . In a paper of 2005, the smuggling prices of transport to a Schengen country in Europe were; from China: USD 10,000 to 15,000; from Afghanistan: USD 4,600 to 6,000; from Ukraine: EUR 5,000 to 10,000, depending on the way of transfer; from Moldova: EUR 2,000 to 3,000 (Futo, Jandl and Karsakova, 2005: 47). It is correct to refer to the important paper of Jandl (2007) also for other aspects of the smuggling business, even if it dates from before the Balkan crisis.

If the hypothesis stating that for SoM entrepreneurs it is all about financial benefits is correct, then it is very important to understand better how the business works and what the real benefits are. Groups and networks that are "highly proficient in illicit trafficking in other commodities" are present where the distances are vast and the risks, dangers and penalties 
very high (Understanding and Responding to the Role of Human Smugglers..., 2016: 11). Court case analyses can be a good place to discover it. The financial structures in large SoM businesses are very often at the same time complex and simple. The financial confidantes who arrange the payments are normally resident in the countries of destination or of provenance, or both. The payments are often made via a hawala bank system ${ }^{38}$ that leaves no traces (Myria, 2016). Authorities should give the needed access to academicians or to civil servants to analyze it. The issue of money should also be discussed. Financial investigations and international collaboration are needed to seizure the criminal goods in the countries of origin or of destination where the criminal money has been referred to or centralized.

\section{A preference for ambiguous legal-illegal instruments}

Close examination of official documents such as Belgian court cases shows that in terms of technique, the Eastern European SoM entrepreneurs frequently make use of false identity documents (Leman and Janssens, 2015: 73-83; see also Aronowitz, Theuermann and Tyurykanova, 2010), and of travel and employment agencies (with overstay afterwards) (Leman, 2002; Leman and Janssens, 2007, 2015: 65-69). It doesn't facilitate the fight against the SoM business.

\section{CONCLUSION}

From our paper, one can conclude that migration and SoM activities occur on the Eastern Balkan and Eastern Borders routes, even if they do not seem to lead to migration and smuggling flows as high as was the case with the Mediterranean routes. SoM will become more expensive for the clients and very probably also more socially selective. It was, however, not our intention to reduce all the smuggling and facilitation work, and still less most of the migration issues, to the large SoM business. There are a lot of local, partial initiatives on the routes. But what has interested us most in this paper, is the possible impact of the large SoM business on what may happen on the Eastern Balkan and Eastern Borders routes, also due to European policies. In order to truly understand the importance, the modus operandi and the success rate of SoM on both routes, one needs a research that

38 The hawala system allows the transfer of money without mediation or transfers via banks. It is religiously or ethnically based on a code of honor and reciprocal trust among the $h a-$ wala dealers. A guarantor on the home front provides a guarantee to a hawala banker in the country of destination who then carries out the payment. What makes the hawala system attractive for smugglers is its anonymity, efficiency and lack of paper trail. 
does not limit its field to the three country clusters on the Eastern Balkan and Eastern Borders routes. The countries of destination and other transit countries in Western Europe should also be included in the research. Additionally, some complementary approaches as suggested under our policy and research challenges should be taken into consideration. Otherwise, the insights remain very biased and underestimate possible SoM dimensions.

In the large SoM business, it is the well-developed transnational criminal organizations that are at work. The SoM entrepreneurs specialize in smuggling routes, surely when migration becomes very difficult, and they are very flexible and inventive in organizing it. They co-operate with other services, for example to obtain false official documents. In those countries they were already doing that in the nineties (see Leman, 2002), so why not now? When needed, they control or use companies, for example travel and employment agencies or transport firms. They bribe officials and civil servants when needed and possible. For the SoM entrepreneurs, there is an almost three-decennia old tradition of doing it. Nowadays, they very often have to cooperate with other SoM entrepreneurs in a distant country of provenance, with lieutenants in the transit and destination countries (see for instance: Toma, Toderita and Damian, 2017: 21). Is the business structured as an "octopus" rather than as a pyramid (Futo, Jandl and Karsakova, 2005)? Anyway, the criminal benefits may be millions of euros. The SoM entrepreneurs invest in destination countries, for example in carwash and catering industry, sectors that enable easy money laundering. In other cases, they invest in real estate in the countries of origin. The smuggling transports often happen in very risky circumstances. Many smugglers treat their clients as merchandise.

In most of the countries we discussed, there is a smuggling tradition from at least the beginning of the 1990s on (starting around the fall of the Berlin Wall). In some cases, where countries have become members of the European Union, this smuggling, mainly of the regionals, has no purpose anymore. In other cases, for instance the CIS countries, it continued, also for the non-regionals (coming from Asia). Ukraine has a particular position.

The detour via Bulgaria for the former Western Balkan transiting migrants has been gaining in importance as a result of pushbacks and pushforwards between Serbia and Macedonia. A different former human smuggling tradition such as Bulgaria-Romania, existed also at least from the 1990s on the Eastern Borders route. The difference with the Bulgaria-Romania route (where it concerns mainly visa trafficking) is that the former smuggling patterns on the Eastern Borders route continue to exist in their 
former multiple formulas and the new ones have been included. Additionally, better flight connections have been introduced on a general level. But this presumes a better financial status of a candidate refugee at departure.

Urgent research is needed to better understand the connections between the Eastern Balkan route and the Eastern Borders route. To do such research successfully, it may be useful to propose it as a mission to the Prague Process. This Process was initiated during the Czech EU Presidency in 2009. Its second Action Plan 2012-2016 led to interesting national reports on irregular migrations and border crossings in Eastern European countries. A new Action Plan, extended to include to the CIS countries, might stimulate such research.

When doing the research, some important questions may be dealt with, namely concerning the continuity with past SoM practices, the diversification of the business, today's role of the social media, and vulnerable persons.

First, the continuity. One may examine if there is continuity between the structures and practices of the 1990s and SoM practices today. Then, the diversification. The current larger businessmen very probably have interests in diversifying their business over different criminal activities (such as $\mathrm{THB},{ }^{39}$ terrorism ${ }^{40}$ drugs and weapons transport), just as in the 1990s (see Leman, 2002; Leman and Janssens, 2015; Europol, 2016: 11-14). Concerning the role of social media, academics teach us how some Romanian websites offer visas, work permits and transport to Moldavians who want to be smuggled into the European Union (Toma, Toderita and Damian, 2017: 12). One may try to better analyze the shifts in the smugglers' recruitment strategies via the virtual world of social media. ${ }^{41}$ At least eleven EU countries (BE, $\mathrm{CZ}, \mathrm{ASH}, \mathrm{FI}, \mathrm{HU}, \mathrm{LT}, \mathrm{NL}, \mathrm{NO}, \mathrm{PL}, \mathrm{SK}, \mathrm{UK}$ ) are being confronted with this phenomenon. ${ }^{42}$ Also, the system with regular flights via the capitals of various countries or via other possible forms of airlifting ${ }^{43}$ is quite unknown.

39 See for suggestions to examine the relation between SoM and THB: Ventrella, 2017.

40 A Syrian migrant smuggler in London and his assistant in Belgium sympathized with ISIS. While in jail, this assistant, who was first admitted to a Brussels reception center, menaced the Kurdish financial manager of the network with beheading by ISIS if he would not change his declarations against him. On his computer, the police found 270 deleted pictures referring to terrorism (Myria, 2017: 90).

${ }^{41}$ See: www.emnbelgium.be/news/experts-migrant-smuggling-gather-be-emn-ncp-roundtable.

42 Summary of EMN Ad-Hoc Query N 1055 of 18 April 2016: Addressing and preventing the use of social media in migrant smuggling.

43 Already in 1995 Ulrich referred to airlifting via helicopter that brought 29 migrants from the Russian Federation into Poland (Ulrich, 1995). 
And then, the question of who can be seen as vulnerable persons. We see that minors are sent to Western Europe to create a future for themselves and their family, but there is also a real risk for many of these children to disappear on route (Derluyn and Broekaert, 2005; Baird, 2013). Not much is known about them. This issue requires much more research. Additionally, the gender dimension is often lacking. From the Iraqi smuggling file that we discussed under "smuggling prices", we learn that at least one migrant testified that some women had to pay in kind for their smuggling transport. A more detailed exploration of some concrete fields and agencies, for instance the way official reception structures really function, ${ }^{44}$ is also a mission for specialized NGOs and academics.

Finally, one should never forget that not only ethically, but also strategically, it is much more interesting to work with (smuggled) migrants than against them. From Myria's experience (2016, 2015), a policy is best when directed at combating SoM entrepreneurs and not the smuggled migrants. A humanitarian approach to the smuggled migrants may constitute an important added value for a successful judicial investigation. When a smuggling transport is intercepted by the police, it is important that these migrants show their mobile telephone to the police force so that they are able to retrieve the relevant messages and telephone calls. This requires an atmosphere of trust. It is not obvious that smuggled migrants should trust the police. What may happen to their family in the country of origin if they collaborate? And are they not often offered a second chance later on by the smugglers? However, in some cases, the smuggled migrants made declarations that were of a relevant plus-value for the investigation. The attribution by authorities of a special protection status and minimal financial income may be helpful to it. The results can be used by the court as objective evidence when motivating their decisions (Myria, 2017).

44 For an example on Röszke, a Hungarian reception center at the border with Serbia, see Amnesty International (2015: 12). 


\section{REFERENCES}

Amnesty International (2015). Fenced Out. Hungary's Violations of the Rights of Refugees and Migrants. London: Amnesty International Publications.

Angeli, D. and Triandafyllidou, A. (2017). Europe, in: M. L. McAuliffe and F. Laczko (eds). Migrant Smuggling Data and Research: A Global Review of the Emerging Evidence Base. Brussels: IOM, 105-136, doi: https://doi.org/10.18356/4fec53d7-en

Aronowitz, A., Theuermann, G. and Tyurykanova, E. (2010). Analysing the Business Model of Trafficking in Human Beings to Better Prevent the Crime. Vienna: OSCE - ODIHR.

Baird, T. (2013). Theoretical Approaches to Human Smuggling. Copenhagen: Danish Institute for International Studies (DIIS) (Working Paper 10), http://pure.diis.dk/ws/ files/56032/WP2013_10_ted_baird_human_smuggling_web.pdf (05 April 2018).

Bilger, V., Hofmann, M. and Jandl, M. (2006). Human Smuggling a Transnational Service Industry: Evidence from Austria, International Migration, 44 (4): 59-93, doi: https:// doi.org/10.1111/j.1468-2435.2006.00380.x

Derluyn, I. and Broekaert, E. (2005). On the way to a better future: Belgium as transit country for trafficking and smuggling of unaccompanied minors, International Migration, 43 (4): 31-56, doi: https://doi.org/10.1111/j.1468-2435.2005.00332.x

Europol (2016). Migrant Smuggling in the EU. Europol Public Information, February. http://frontex.europa.eu/trends-and-routes/eastern-borders-route/traffickersfacebook-europol-report (15 August 2018)

Fargues, P. (2013). EU Neighbourhood Migration Report 2013. Brussels: Migration Policy Centre.

Frontex (2016). Eastern Borders Route. Warsaw, http://frontex.europa.eu/trends-androutes/eastern-borders-route/ (06 April 2018).

Frontex (2017a). Eastern Partnership. Annual Risk Analysis. Warsaw.

Frontex (2017b). Western Balkans Quarterly. Quarter 1, January - March 2017.

Frontex (2017c). Eastern Partnership. Risk Analysis Network Quarterly, Quarter 1, JanuaryMarch.

Frontex (2018). Eastern Borders Route. Warsaw, http://frontex.europa.eu/trends-androutes/eastern-borders-route/ (06 April 2018).

Futo, P., Jandl, M. and Karsakova, L. (2005). Illegal Migration and Human Smuggling in Central and Eastern Europe, Migracijske i etničke teme, 21 (1-2): 35-54.

International Centre for Migration Policy Development (ICMPD) (2013). Yearbook on Illegal Migration, Human Smuggling and Trafficking in Central and Eastern Europe. A Survey and Analysis of Border Management and Border Apprehension. Vienna.

International Organization for Migration (IOM) (2017a). Mixed Migration Flows in the Mediterranean and Beyond. Compilation of Available Data and Information. Reporting Period 2016. Brussels.

IOM (2017b). Mixed Migration Flows in the Mediterranean. Compilation of Available Data and Information August 2017. DTM report. Brussels.

Jandl, M. (2007). Irregular Migration, Human Smuggling and Eastern Enlargement of the European Union, International Migration Review, 41 (2): 291-315, doi: https://doi. org/10.1111/j.1747-7379.2007.00069.x 
Jaroszewicz, M. and Kindler, M. (2015). Irregular migration from Ukraine and Belarus to the EU: A risk analysis study. Warsaw: Centre of Migration Research, University of Warsaw. (CMR Working Papers 80/138), http://hdl.handle.net/10419/140863 (10 August 2018).

Kyuchukov, L. (2016). Impact of the Refugee Crisis on Bulgarian Society and Politics: Fears But No Hatred. Sofia: Friedrich-Ebert-Stiftung, Office Bulgaria.

Leman, J. (2002). L'Etat gruyère. Mafias, visas et traite en Europe. Brussels: Mols editions.

Leman, J. and Janssens, S. (2015). Human Trafficking and Migrant Smuggling in Southeast Europe and Russia. Criminal Entrepreneurship and Traditional Culture. London - New York: Palgrave Macmillan, doi: https://doi.org/10.1057/9781137543646

Leman, J. and Janssens, S. (2007). Travel agencies as a linking element for human smuggling and trafficking from Eastern Europe, Studi emigrazione, 44 (166): 443-459.

Lilyanova, V. (2016). The Western Balkans - Frontline of the Migrant Crisis. European Parliamentary Research Service (EPRS), (Members' Research Service, PE 573.949), http://www.europarl.europa.eu/RegData/etudes/BRIE/2016/573949/EPRS_ BRI\%282016\%29573949_EN.pdf (05 April 2018).

Markov, I. (2009). Ukrainian Labour Migration in Europe. Findings of the Complex Research of the Processes of Ukrainian Labour Immigration. Lviv: Caritas Ukraine.

Mosneaga, V. (2013). Illegal Moldovan Migration to the European Union. Florence: European University Institute, Robert Schuman Centre for Advanced Studies - Migration Policy Centre (CARIM-East Explanatory Note 13/85).

Myria (2013). Jaarverslag Mensenhandel (Yearly Report Human Trafficking and Migrant Smuggling). Brussels.

Myria (2015). Jaarverslag Mensenhandel (Yearly Report Human Trafficking and Migrant Smuggling). Brussels.

Myria (2016). Jaarverslag Mensenhandel (Yearly Report Human Trafficking and Migrant Smuggling). Brussels.

Myria (2017). Jaarverslag Mensenhandel (Yearly Report Human Trafficking and Migrant Smuggling). Brussels.

Quercia, P. (2017). The Balkans and the Black Sea, Osservatorio Strategico, 19 (5): 17-20.

Remáč, M. and Malmersjo, G. (2016). Combatting Migrant Smuggling into the EU. Main Instruments. European Parliamentary Research Service (EPRS) (Policy Cycle Unit, PE 581.391), http://www.europarl.europa.eu/RegData/etudes/BRIE/2016/581391/ EPRS_BRI\%282016\%29581391_EN.pdf (10 August 2018).

Republic of Moldova. Migration Profile Light (2015). Prague Process.

Schiopu, O. I. (B.) and Dumitrache Ionescu, A. A. (2016). Migrants' Smuggling is Knocking at the Danube's Door. Threats at the Romanian State Border, Journal of Danubian Studies and Research, 6 (2), http://journals.univ-danubius.ro/index.php/ research/article/view/3874/3936 (10 August 2018).

Toma, B., Toderita, A., and Damian, A. (2017). Improving and Sharing Knowledge on the Internet Role in the Human Trafficking Process. Bucharest: Surf and sound.

Townsend, M. (2016). 10,000 refugee children are missing, says Europol, The Guardian, January 30, https://www.theguardian.com/world/2016/jan/30/fears-for-missingchild-refugees (04 April 2018). 
Ulrich, C. (1995). Alien Smuggling and Uncontrolled Migration in Northern Europe and the Baltic Region. Helsinki: The European Institute for Crime Prevention and Control (Heuni Paper 7), http://heuni.fi/material/attachments/heuni/papers/6Knp7r3Db/ Heuni.pdf (05 April 2018).

Understanding and Responding to the Role of Human Smugglers in Migration. Policy Brief, September (2016). The Global Initiative Against Transnational Organized Crime RHIPTO, http://globalinitiative.net/wp-content/uploads/2016/09/Understanding-andResponding-to-the-Role-of-Human-Smugglers-in-Migration.pdf (04 April 2018).

UNHCR, UNICEF and IOM (2017a). Refugee and Migrant Children - Including Unaccompanied and Separated Children - in the EU. Overview of Trends in 2016, https:// data2.unhcr.org/ar/documents/download/55971 (05 April 2018).

UNHCR, UNICEF and IOM (2017b). Refugee and Migrant Children - Including Unaccompanied and Separated Children - in the EU. Quarterly Overview of Trends January - March, https://www.unicef.org/eca/sites/unicef.org.eca/files/eca-dataprodInfographic_Children_and_UASC_2017_11July.pdf (05 April 2018).

UNHCR (2017a). Desperate Journeys, February, https://data2.unhcr.org/en/documents/ download/53994 (05 April 2018).

UNHCR (2017b). From a Refugee Perspective: Discourse of Arabic speaking and Afghan refugees and migrants on social media from March to December 2016, April, http://www. unhcr.org/5909af4d4.pdf (05 April 2018).

Ventrella, M. (2017). Identifying Victims of Human Trafficking at Hotspots by Focusing on People Smuggled to Europe, Social Inclusion, 5 (2): 69-80, doi: https://doi. org/10.17645/si.v5i2.896

Weber, B. (2017). The EU-Turkey Refugee Deal and the Not Quite Closed Balkan Route. Sarajevo: Friedrich-Ebert-Stiftung Dialogue Southeast Europe. 


\title{
Krijumčarenje ljudi na istočnobalkanskoj ruti i ruti na istočnim granicama Europe
}

\author{
Johan Leman, Stef Janssens
}

\section{SAŽETAK}

Autori predlažu analizu zbivanja povezanih s krijumčarenjem migranata (a neposredno i s tranzitnim migracijama) na istočnobalkanskoj ruti (Bugarska - Rumunjska) i ruti na istočnim granicama (Moldavija, Ukrajina i Bjelorusija) otprilike od 2015. godine. S obzirom na ozbiljne kontrole na zapadnobalkanskoj ruti i nakon dogovora EU-a i Turske iz travnja 2016., nove rute, od kojih svaka ima vlastitu desetogodišnju tradiciju krijumčarenja, za određene migrante u tranzitu (i krijumčare migranata) predstavljaju moguću alternativu zapadnobalkanskoj ruti. Počevši od statističkih podataka, autori pokazuju da će se nove rute sigurno djelomično integrirati, ali i da nije dovoljno jasno u kojoj se mjeri i kako to događa. Navode podatke o dosadašnjim spoznajama. Istodobno postaje jasno da je teško shvatiti procese i složenost aktivnosti krijumčarenja migranata uslijed problema povezanih sa službenim označivanjem i nedostatka sveobuhvatnog pristupa, zbog kojeg se u obzir uzimaju samo određeni dijelovi ruta. Umjesto povezivanja djelomičnih podataka trebalo bi omogućiti praćenje procesa od odredišnih do polazišnih zemalja. U većini slučajeva zemlje u okviru istočnobalkanske rute i rute na istočnim granicama samo su tranzitne zemlje. Cijela struktura ostaje izvan dosega. Kako bi istaknuli važnost sveobuhvatnog pristupa, autori analiziraju određene dokumente iz jedne od mogućih odredišnih zemalja (Belgije). U zaključku iznose prijedloge za buduća istraživanja.

KLJUČNE RIJEČI: istočna granica, istočni Balkan, tranzitne migracije, krijumčarenje migranata 